\title{
INTERNALIZING ISLAMIC VALUES IN ELECTROCHEMISTRY LEARNING
}

\section{Cucu Zenab Subarkah}

State Islamic University (UIN) Sunan Gunung Djati Bandung Jl. A. H. Nasution No. 105, Bandung, Jawa Barat.

Email: zenabsc@gmail.com

\section{Risa Rahmawati Sg}

State Islamic University (UIN) Sunan Gunung Djati Bandung Jl. A. H. Nasution No. 105, Bandung, Jawa Barat.

Email: sunaryarisar@gmail.com

\author{
Ajeng Dalli \\ State Islamic University (UIN) Sunan Gunung Djati Bandung, Indonesia. \\ Jl. A. H. Nasution No. 105, Bandung, Jawa Barat. \\ Email: ajengalamiah@gmail.com
}

\begin{abstract}
The purpose of this paper is to describe a potential way of integrating the knowledge of electrochemistry with a story in the Al-Qur'an particularly in the sura of Al-Kahfi, verse 83-96. The story tells about an implicit understanding of the concept of electro chemistry. Having the story in the learning of electrochemistry is aimed to internalizing the spirit of Islam in the learning of electro chemistry. Using a classroom action research, this study involved 95 students who are taking the course of Basic Chemistry 2. This study used three instruments, namely: observation sheet of students activity, observation sheet of students attitute, and self-assessment questionnaire. Based on the data, the study found that students were considerably active in each stage of the learning process with the average of activitiy is $78 \%$ (good). With regards to attitude, only aspect of responsibility that was not well appeared while the aspects of religious curiosity, cooperative, and communication relatively presented
\end{abstract}

Keywords: Al-Qur'an, Electrochemistry, Internalization, Character Values.

\section{ABSTRAK}

Tulisan ini bertujuan untuk membahas integrasi pembelajaran elektrokimia dengan ayat AlQur'an Surat Al-Kahfi Ayat 83-96. Surat Al-Kahfi Ayat 83-96 berisikan kisah teladan Zulkarnain dan teknik pencegahan korosi. Integrasi Surat Al-Kabfi Ayat 83-96 pada pembelajaran konsep elektrokimia dimaksudkan untuk menginternalisasi nilai- nilai karakter mahasiswa. Metode penelitian yang digunakan adalab metode penelitian tindakan kelas dengan subjek penelitian 95 orang mahasiswa yang sedang mengambil mata kuliah Kimia Dasar 2. Instrumen penelitian terdiri dari tiga jenis, yaitu lembar observasi aktivitas mahasiswa, lembar observasi sikap, dan angket penilaian diri. Data yang diperoleh selanjutnya diolah dengan menggunakan statistika persentase. Hasil observasi aktivitas mahasiswa menunjuk.kan kategori baik pada setiap tahapan pembelajaran dengan rata-rata keterlaksanaan 78\%. Sementara hasil 
observasi dan penilaian diri sikap mahasiswa menunjukkan karakter mahasiswa yang muncul selama pembelajaran adalab religius, rasa ingin tabu, kerja sama, dan komunikatif. Sedangkan karakter tanggung jawab belum muncul dengan baik.

Kata Kunci: Al-Qur'an, Elektrokimia, Internalisasi, Nilai-nilai Karakter, Mahasiswa.

\section{INTRODUCTION}

Character education is one of the efforts in generating the human resources that are able to build the nation. National Long Term Development Plan or Rencana Pembangunan Jangka Panjang (RPJPN) 2005-2025 describes character education as the first mission of the national development.

.... Embodiment of nation's character which is strong, competitive, noble, and has Pancasila-based moral is characterized by disposition and behavior of humans and Indonesian people who are heterogeneous, religious, and devout to oneness of God, glorious, tolerant, cooperative, patriotic, dynamic, and IPTEK-oriented (Kemendiknas, 2011).

The effort of embodying the nation's character which is strong and noble has been entrusted in RPJPN. Therefore, educational institutes must carry out the national development missions in the form of applying the characteristic education in each lesson. An educator must design a learning activity which integrates each subject with the character education. This is a must because, according to Hasanah (2013, p. 13), excellent civilization is built by all nation elements which have strong, positive, and sturdy characters.

In reality, education, all this time, really prioritizes cognitive aspects. For instance, it gives much homework and does not insist on building the character in the learning. The fact that educational world and other social phenomena, which emerge among students, are students' fights, drugs, free sex, and fraud in various kinds of test (Andriansyah Moch, 2015). Even, the recent thing which occurs is invitation for bikini party after graduation of 2015 National Test of Senior High School (Handayani, 2015, p. 1).

Apart from the cases of Senior High School students, based on the research which has been done by Lutfiyah (2014), there are students' characters which not good during the learning process. For instance, there is deceitfulness during lab work by forging the observation data. Some cases which have been mentioned are educational problems which must be overcome in order to have the strong, competitive, and noble nation's characters as the aspiration of national development.

Hasanah (2013, p. 23) says that in Al-Qur'an there are core ethical values which are outlined to be some behaviour source values. The values are 
value of faith, honesty, responsibility, care, discipline, bravery and citizenship. Internalization process of these core ethical values has to be done through teaching, modelling, motivating, accustoming and upholding of rules so as to generate the characteristic behaviour to students.

Relating to internalization process of the characteristic values on each subject, Nugroho (2008, p. 304) says that chemical lesson contains a lot of regularity values which direct to the exalting of Allah SWT. If the chemical phenomena are dug deeper and accompanied by the verses of Al-Qur'an which explain them, then there will be acquired religious values which can be made as a base in students' character development of learning.

One of the chemical concepts related to daily life which can be found in Al-Qur'an is electrochemistry concept. In sura AL-Kahfi, verse 96, AlQur'an explains that Zulkarnain built a castle from strong and tall iron materials by plating the iron with copper. Hence, technique of anti-corrosion protection which was done by Zulkarnain, the destroyers Yajuj Ma'juj cannot even destroy the built iron castle. This can be made an analogy that to avoid destruction of people's character, it is required the effort of protection or prevention, one of them is by implanting and strengthening the values of builder. The story in Al-Qur'an is the thing which can be integrated into chemistry subject to internalize the character values in learning.

Electrochemistry is a concept that needs to have direct experiences in order to get better understand. Experiences in science should consider scientific approach in which 5 activities are involed, namely: observing, questioning, collecting data, associating and communicating. Implementing the scientific approach will not only acquire direct learning experiences but also reinforce students' character (Kemendikbud, 2013).

Based on the facts and the explanations above, there is a question "how can the learning or chemistry internalize the values of students' character builder?" Solution to the problem is tried by doing the learning process using the scientific approach containing verses of Al-Qur'an to the concept of electrochemistry. Such learning has an opportunity to internalize the values of students' character builder. Each stage of scientific approach can elicit the characters which can be observed during the learning process. Therefore, there has been done a research regarding the learning of electrochemistry containing verses of Al-Qur'an to develop the values of students' character builder.

The research was done at Chemistry Education Study Program of UIN Sunan Gunung Djati Bandung. The research subject is the students in the second semester, in $\mathrm{A}$ and $\mathrm{B}$ classes. Electrochemistry material is one of the materials of the Basic Chemistry course 2 which is presented to the second semester students. The electrochemistry learning which contains the verses 
of Al-Qur'an is proper to be applied at UIN specially Chemistry Education Study Program which has visions and missions in carrying out Islamic-valuesbased learning. The technique of research data collecting can be seen in Table 1.

Tabel 1. Data Collecting Technique

\begin{tabular}{|l|l|l|l|l|}
\hline No. & $\begin{array}{l}\text { Data } \\
\text { Sources }\end{array}$ & \multicolumn{1}{|c|}{ Kinds of Data } & $\begin{array}{l}\text { Data Collecting } \\
\text { Technique }\end{array}$ & Instrument \\
\hline Students & $\begin{array}{l}\text { Students' activity } \\
\text { during the learning } \\
\text { process }\end{array}$ & $\begin{array}{l}\text { By observing } \\
\text { students activity } \\
\text { during teaching and } \\
\text { learning process }\end{array}$ & $\begin{array}{l}\text { Activity } \\
\text { observation } \\
\text { sheet }\end{array}$ \\
\hline & Students & Character builder & $\begin{array}{l}\text { Character w wen } \\
\text { observation when } \\
\text { the learning was } \\
\text { taking place and }\end{array}$ & $\begin{array}{l}\text { Observation } \\
\text { sheet attitudes and } \\
\text { skills }\end{array}$ \\
\hline Students & $\begin{array}{l}\text { Students' } \\
\text { assessment after the } \\
\text { learning }\end{array}$ & $\begin{array}{l}\text { Filling } \\
\text { assessment } \\
\text { questionnaire }\end{array}$ & $\begin{array}{l}\text { Self- } \\
\text { assessment } \\
\text { questionnaire }\end{array}$ \\
\hline
\end{tabular}

Based on the Table 1 above, there are three kinds of data which are obtained from research results, namely; the data concerning students' activity during the learning process, the data concerning students' attitude and skills, and the characters which appear in each stage of learning.

The research implementation was helped by an observer having a duty in observing the learning activities by using observation sheets.

\section{DISCUSSION}

\section{The Learning of Electrochemistry Containing Verses of Al-Qur'an}

The learning containing verses of Al-Qur'an makes the verses of AlQur'an one of the learning sources. Hakim (2012, p. 67) presents the aspects of Islamic teaching values which are in the verses of Al-Qur'an which can be differentiated into three types, namely; values of aqî̀dah, ibâdah, and akblâq (morals). The values of aqîdah teach humans to believe in their God; the values of ibâdah teach about the pursuit of God's favour as the base to each deed; and the values of akblâq teach to behave in accordance with the right and good courtesy. These values of morals or characters are implicitly presented in the verses of Al-Qur'an.

Nugroho (2008, p. 304) says that chemistry contains a lot of regularity values which direct to the exalting of Allah SWT. If the chemical phenomena 
are extracted deeper and accompanied by the verses of Al-Qur'an which explain them, then there will be acquired religious values which can be made as a base of students' characteristic development in learning. Nugroho further says that Q.S. Al-Kahfi [18]: 96 explains reduction and oxidation reaction and electro chemistry in concept application rank, that is corrosion prevention.

In addition, based on Q.S. Al-Kahfi [18]: 91-98, there are some characters of Zulkarnain in his story which constitute the character builder values. More clearly, details of religious characters and other characters in the story can be seen in Table 2 .

Table 2. Contents of Zulkarnain's Story and The Observed Character Builder Values

\begin{tabular}{|l|l|}
\hline \multicolumn{1}{|c|}{ Contents of Story } & $\begin{array}{l}\text { The Observed Character } \\
\text { builder Values }\end{array}$ \\
\hline $\begin{array}{l}\text { Q.S Al-Kahfi [18]: 91-98 contains precious lessons } \\
\text { about Dzulkarnain having humble character with his } \\
\text { cleverness and power as well as patience. }\end{array}$ & $\begin{array}{l}\text { Religious: Honest, humble, } \\
\text { patient, noble }\end{array}$ \\
\hline $\begin{array}{l}\text { The secret of strength of the copper-plated iron wall } \\
\text { built by Zulkarnain was disclosed after reactions of } \\
\text { electrochemistry were found out; that was, the copper } \\
\text { which could protect the iron was caused by its standard } \\
\text { reduction potential. It caused the castle built by } \\
\text { Zulkarnain was not susceptible to corrosion. The sotry } \\
\text { proved that Iskandar Zulkarnain was a king who liked } \\
\text { science. }\end{array}$ & Curiousity \\
\hline $\begin{array}{l}\text { Zulkarnain led constraction of a castle by working } \\
\text { together in the construction as the effort of avoiding a } \\
\text { destrcution caused by Yakjuj and Makjuj. }\end{array}$ & Cooperative \\
\hline $\begin{array}{l}\text { As a leader, Zulkarnain was in charge of leading and } \\
\text { working. }\end{array}$ & Responsible \\
\hline $\begin{array}{l}\text { Zulkarnain always conveyed Allah SWT's orders in wise } \\
\text { and diplomatic ways. }\end{array}$ & Communicative \\
\hline
\end{tabular}

In chemical learning which contains verses of Al-Qur'an, the verses investigated are the stories of Zulkarnain in Q.S. Al-Kahfi, [18]: 83-98. Zulkarnain was one of the figures whose story was perpetuated by Allah in Al-Qur'an. This story was explained after Prophet Khidir a.s. Just as the story, the story of Zulkarnain also contains full of wisdom. These are the verses which explain the story of Zulkarnain, namely Q.S. Al-Kahfi [18]: 8398 which means:

(Verse 83): "They will ask you (Mubammad) about Dzulkarnain. Tell them: "I will tell you the story about bim" (Verse 84): "In fact, We have given him the power on earth, and 
We have given him the way (to reach) everything." (Verse 85): "So he took a way." (Verse 86): "Until if he has come to the place where the sun goes down, he saw the sun sinking in a black muddy sea, and he found a group of people, we ask: "O, Dzulkarnain, you may torture or do goodness to them." (Verse 87): "Diulkarnain says: "If there is a tyrannical person, then we will punish bim. Then he will be returned to his God. Then God will punish him with an unequalled torment." (Verse 88): "If the people are devout and pious, then they will gain the best rewards, and we will give them the easy (orders) from our orders." (Verse 89): "Then he took (another) way." (Verse 90): "Until if he has come to the place where the sun rises (in the east), he finds the sun irradiating a group of people to whom we do not make something which protects them from the sunlight." (Verse 91): "Thus, Our science actually covers everytbing which is in it." (Verse 92): "Then he took (any other) way." (Verse 93): "Until if he arrives between two mountains, he finds in front of the both hills a group of people who almost do not understand conversation." (Verse 94): "They say: "O Dzulkarnain, Yajuj and Ma'juj are actually the people who make destructions on earth, so can we give you a payment so that you build a wall between us and them?" (Verse 95): "D zulkarnain says: "What has been endorsed by my God to me is better. So belp me with the strength of (bumans and tools) so that I build the wall between you and them." (Verse 96): "Give me the pieces of iron", until if the iron is already level with the both (peaks) of mountains, said Dzulkarnain: "Blow (the fire)". Until if the iron bas already turned red like the fire, he said: "Give me the (boiling copper) so that I pour it on the hot iron." (Verse 97): "Therefore, they cannot climb it and they cannot (also) perforate it." (Verse 98): "D zulkarnain says: "This (wall) is the mercy from my God. So, if my God's promise has come, He will make it completely shattered; and my God's promise is right."(Q.S. Al-Kabfi [187: 83-98)

The verses above are part of Iskandar Zulkarnain's story, a brawny and brave king having a wide powerful area. However, he remained devout and obedient to his God's orders. In one of his journey, he arrived in an area between two mountains, the resident of the Yakjuj and Makjuj who often made destructions on earth. Therefore, people asked for Zulkarnain's helps in order to build a castle to protect them from the destroyers' disruption. Zulkarnain then asked the people to gather the iron and to burn it until it turned red like the fire. Zulkarnain then poured the hot copper liquid on the hot iron. The wall which was made of the iron became very strong and could not be climbed and be perforated.

Why did Zulkarnain pour the copper liquid on the castle which was made of the iron material? It is for protecting the iron from corrosion process. Corrosion is a metal destruction process caused by a electrochemistry process involving a reaction of oxidation and reduction. Corrosion on iron is marked by formation of rust. The reaction of rustiness is very complicated, but it can be simplified by reaction of oxidation on metal surface as follows: 
$\mathrm{Fe}(s) \rightarrow \mathrm{Fe}^{2+}(a q)+2 \mathrm{e}^{-}$

Electro which is released by iron is used to reduce oxygen at atmosphere becoming water on cathode in another zone of the metal surface.

$\mathrm{O}_{2}(g)+4 \mathrm{H}^{+}(a q)+4 \mathrm{e}^{-} \rightarrow 2 \mathrm{H}_{2} \mathrm{O}(l)$

The whole redox reaction:

$2 \mathrm{Fe}(s)+\mathrm{O}_{2}(g)+4 \mathrm{H}^{+}(a q) \rightarrow 2 \mathrm{Fe}^{2+}(a q)+2 \mathrm{H}_{2} \mathrm{O}(l)$

The above reaction occurs in acid ambience because it involves $\mathrm{H}^{+}$ some of which originate from reaction of carbon dioxide $\left(\mathrm{CO}_{2}\right)$ in atmosphere with water which forms carbonic acid $\left(\mathrm{H}_{2} \mathrm{CO}_{3}\right)$.

The next is ion $\mathrm{Fe}^{2+}$ which is formed to be dioxide again by oxygen in anode. The reaction is as follows:

$4 \mathrm{Fe}^{2+}(a q)+\mathrm{O}_{2}(g)+(4+2 \mathrm{x}) \mathrm{H}_{2} \mathrm{O}(\zeta) \rightarrow 2 \mathrm{Fe}_{2} \mathrm{O}_{3} \cdot \mathrm{xH}_{2} \mathrm{O}(s)+8 \mathrm{H}^{+}(a q)$

The form hydrated from iron (III) and oxide $\left(\mathrm{Fe}_{2} \mathrm{O}_{3} \cdot \mathrm{xH}_{2} \mathrm{O}\right)$ is known as rust (Chang, 2005, p. 216).

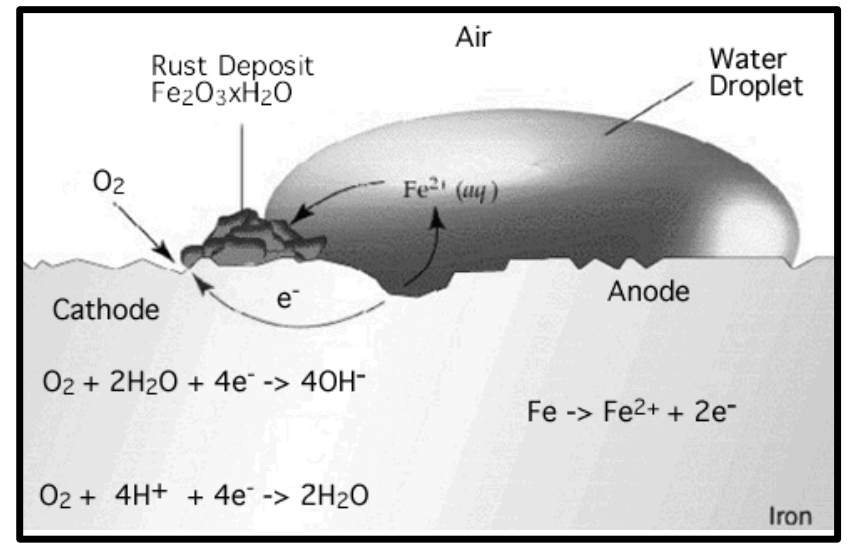

Figure 1. Corrosion Mechanism of Iron.

(Source: Chemistry: The Central Science, 2000)

There is an underlying question, why did Zulkarnain use the copper as the iron layer? Copper or Cuprum $(\mathrm{Cu})$ is metal which is frequently used because it is a good conductor and heat. Copper is used for the surface plating because it can cover a material surface which is well plated. The copper surface plating is required for further plating with nickel which is then followed by the last plating with chrome. Copper is used as a beginning layer to get good sticking and to protect steel from acidity of sulphate copper solution. The physics characters of Copper are:

1. Reddish and shiny metal.

2. It can be smitten and warped, and constitutes the conductor of heat and electricity.

3. The melting point is $1.083^{\circ} \mathrm{C}$, the boiling point is $2.301^{\circ} \mathrm{C}$ 
4. The weight for kind of copper is about $8.92 \mathrm{gr} / \mathrm{cm}^{3}$. The chemistry characters of Copper are:

1. It is difficult to be oxidized in the dry air; however, if it is heated, it will form copper oxide $(\mathrm{CuO})$.

2. In the moist air, it will turn into carbonic compound or wet rust, according to reaction:

$2 \mathrm{Cu}(\mathrm{s})+\mathrm{O}_{2}(\mathrm{~g})+\mathrm{CO}_{2}(\mathrm{~g})+\mathrm{H}_{2} \mathrm{O}(\mathrm{l}) \rightarrow(\mathrm{CuOH})_{2} \mathrm{CO}_{3}(\mathrm{aq})$

3. It cannot react with either liquid $\mathrm{HCL}$ or liquid $\mathrm{H}_{2} \mathrm{SO}_{4}$ solution.

4. It can react with both sticky $\mathrm{H}_{2} \mathrm{SO}_{4}$, liquid $\mathrm{HNO}_{3}$ and liquid $\mathrm{Cu}(\mathrm{s})+$ sticky $\mathrm{H}_{2} \mathrm{SO}_{4}(\mathrm{aq}) \rightarrow \mathrm{CuSO}_{4}(\mathrm{aq})+2 \mathrm{H}_{2} \mathrm{O}(\mathrm{l})+\mathrm{SO}_{2}(\mathrm{~g})$.

5. $\mathrm{Cu}(\mathrm{s})+$ sticky $4 \mathrm{HNO}_{3} \rightarrow \mathrm{Cu}\left(\mathrm{NO}_{3}\right)_{2}+2 \mathrm{H}_{2} \mathrm{O}(\mathrm{l})+2 \mathrm{NO}_{2}(\mathrm{~g})$

6. $\mathrm{Cu}(\mathrm{s})+$ liquid $8 \mathrm{HNO}_{3} \rightarrow 3 \mathrm{Cu}\left(\mathrm{NO}_{3}\right)_{2}+4 \mathrm{H}_{2} \mathrm{O}(\mathrm{l})+2 \mathrm{NO}(\mathrm{g})$

7. In general, copper layer is the surface layer which must be plated again with Nickel and Chrome.

\section{Character Education in Learning of Electrochemistry Containing Verses of Al-Qur'an}

The process of internalizing characters should bring students to know the values of character cognitively, to comprehen the values in affective ways, and finally to have real experiences. The very important stage as key of the real experiences is the stage of conatio, in which the students have a passion to carry out the values. The step to guide the students to the stage of conatio is the conative step. The character education has to be systematically fought for, getting started from value introduction cognitively, value comprehension in affective way and willpower formation in conative way (Gunawan, 2013, p. 40).

In learning of electrochemistry containg verses of Al-Qur'an, students' characters, that's the emergence is controlled in the learning process, are the religious, curious, communicative, responsible and cooperative characters. The verses of Al-Qur'an containing the character builder values are mentioned, indeed, in Al-Qur'an; however, the verses which are written in this paper are just a half. Some of them are as follows:

1. Religious

Being religious in learning can be illustrated through their attitudes in applying the followed religious views. According to Kemendiknas (2011), one of the religious attitude indicators is adoring the greatest God through various topics in various subjects. Some Islamic teachings regarding the characters which must be applied in the learning design are in verses of $\mathrm{Al}$ Qur'an which mean as follows:

a. Patient 
"Then if you have had the strong willpower, then be patient to Allah. In fact Allah loves people who are patient to Him.” (Q.S. Ali Imrân [3]: 159)

b. Humble

..... "and be humble to the people who follow you, they are the devout people." (Q.S. Asy-Syuara' [26]: 215).

c. Having good morals following Prophet Muhammad ".... And as a matter of fact, you (Muhammad) really have glorious morals.”(Q.S. Al-Qalam [68]: 4).

d. Honest

"..... O the believers, why did you say what you did not do? The hate is very big beside Allah that you said what you did not do." (Q.S. Ash-Shaff [37]: 2-3).

2. Curious

"Musa said to Khidir: "May I follow you so that you teach me the right science among sciences which have been taught to you?" (Q.S. Al-Kahfi [18]: 66).

3. Communicative

"And be simple when you walk and soften your voice. In fact, the worst voice is the voice of ass."(Q.S. Luqmân [31]: 19).

4. Responsible

"And people who are devout and do the pious deeds, we do not burden the obligation to someone except his capability, they are occupants in heaven; they are eternal in it." (Q.S. Al-A'râf [7]: 47).

5. Cooperative

".... And you bave to help each other in (doing) virtues and pieties, and do not help each other in making sins and infractions, and you have to be pious to Allah. In fact, Allah's torments are very severe."(Q.S. Al-Mâidah [5]: 2).

\section{Students' Activities in the Learning of Electrochemistry by Internalizing Verses of Al-Qur'an}

The process of learning chemistry using the scientific approach containing the verses of Al-Qur'an consists of five stages, namely: observing, questioning, collecting data, associating and communicating. Each stage is accompanied by worksheets which have to be filled by students. These five stages are integrated with the learning sources, one of which is Al-Qur'an. The explanations about description of chemical learning design containing verses of Al-Qur'an are as follows:

1. Stage of Observing

The process of observing can be done through two ways, namely:

a. Observing phenomena directly (direct observation on an object/a thing in the nature).

b. Observing phenomena indirectly (observation through pictures, reading articles about a phenomenon which can be given through worksheets). 
The stage of observing is the stage of stimulus giving in the form of discourses, one of them is the discourse about technique of corrosion prevention in Al-Qur'an which is done by Dzulkarnain. Afterward, every student analyzes the discourses through the reading activity, construes and takes the contents from Al-Qur'an. The researcher displays pictures and videos about the losses which are brought about by corrosion. Students are directed to analyze the problems and the losses related to the corrosion phenomena.

The stage of observing is the most important one because it determines the success of the next stages. From attitude assessment aspect, this stage is the students' activity to elicit and develop religious (honest) as well as curious attitude. During the process, the researcher directs and gives stimulus, while the students pay attention and find out from Al-Qur'an and other sources.

Based on the research, the students observed well when given some stimulus. When one of the students read the verses of Al-Qur'an about the corrosion prevention, other students listened carefully. When pictures and videos were displayed, the students mentioned the corroded objects which were displayed on slides and mentioned other examples occurring in daily life. Generally, most of the students paid attention well and were interested in the learning.

2. Stage of Questioning

The stage of questioning is the continuation from the stage of observing. In this stage, every student submitted questions or problems in accordance with the observation results which were orally expressed in the discussion forum. The students were enthusiastic doing the discussion to select questions which would be submitted which they thought relevant. From the discussion results, one question or problem was selected and written. Then it was re-written on the worksheets in the form of problem formulation.

The questions which are submitted by students are collected by the researcher. The researcher identifies the questions and then determines some questions which are relevant to the learning objectives which will be achieved. The questions which are in accordance with the learning objectives are: (a) why does the corrosion occur? (b) What does cause it? (c) How to overcome or prevent the corrosion as Zulkarnain did? These are the questions which are selected and are emphasized to the students to find the answers in the stage of data collecting.

Students' attitude which is expected to appear in the stage of questioning in the learning is the curious attitude and the ability to communicate it. Thereby, the students are trained to be able to formulate the 
problems by questioning in communicative way. The curious attitude can be seen from the emergence of questions which are submitted by students. Students were enthusiastic submitting the questions orally by expressing argumentations for the reason why they chose the questions. In this stage, the students are indirectly trained to develop the ability of communication. Based on the observation results, more than four students submitted questions directly accompanied by argumentations as representative from group. Some of the questions have accorded with the questions which are relevant to the learning objectives even though the reductions which are conveyed by the students are a little bit different. Thereby, it can be said that the process of questioning can be said well-implemented with the emergence of relevant questions expressed by the students.

3. Stage of Collecting Data

The stages which are done are:

a. Students submit hypotheses in the form of tentative answers towards the emerging questions or problems. The hypothetical formulations can be written on the worksheets.

b. Students design and do experiments (if the method is experimental) or collect the data from various sources (if the method is nonexperimental) to test the hypotheses. This experimental design can be written on the worksheets.

c. Students observe and record the experimental results (if the method is experimental) or write down the secondary data from various sources (if the method is non-experimental). It can be written on the worksheets.

d. Students analyze the data by answering a sequence of questions which is consecutively given on the worksheets until they can determine the hypothetical truth.

In the stage of collecting data, the researcher directs the students to test the hypotheses by exploring the learning sources from Al-Qur'an, textbooks, interpretations, internet, and so on. In the process, the students are given the worksheets which consist of seven essay items. The worksheets are done in group and are finished at the appointed time.

This stage is the students' activity to elicit and develop religious attitude; that is pride, to seriously use and recite Al-Qur'an as one of the learning sources, to develop curiosity in seeking the data from various sources, to be responsible for finishing the worksheets rightly and punctually, and to cooperatively divide the tasks with their friends to finish the worksheets.

In the stage of collecting the data, students seek and solve problems and often ask friends or researcher due to the needs of available problem 
solving. The assessment process which is done in the learning makes groups of students more proactive in finishing the worksheets. It can be seen from the existence of task division to each member of group. For instance, task division for seeking information from various sources, and task division for finishing the questions in the worksheets. Tendency of the groups mostly make one person do one item, so that responsible and cooperative attitudes appear in the learning.

In the process of doing the items the students need sources from AlQur'an and interpretation. They use various interpretation books. Some of them bring the interpretation, and some others take the sources from internet. In addition, the students often submit the questions for some items because they think that the explanations from the used textbooks are less adequate. This is the thing becoming one of the obstacles happening in the learning process. However, it becomes a challenge for students to seek the more complete information. Even so, generally the stage of collecting the data can be implemented well enough.

4. Stage of Associating

Stage of associating is the stage in which the students discuss in groups, fill the worksheets, and draw some tentative conclusions from the problematical formulations and the questions which are in the worksheets. This stage will demand the students to elicit the religious, curious, responsible and cooperative attitudes just as in the stage of collecting the data.

Stage of associating is the students' activity to explore and conduct the problematical formulations, the learning sources as well as the results of groups' discussion. The students associate by discussing and then concluding. The conclusion reductions of each group are different, but the point is nearly the same. The conclusion which they state is that the corrosion occurs because there are cause factors, such as water, moisture, air, electrolyte, uneven surface and formation of electrochemistry cell. In addition, the students outline the corrosion's reaction mechanism. After finding out some causes of corrosion, the students propose some prevention based on principles of electrochemistry.

Just as the previous stage, that is the stage of collecting the data, religious and cooperative attitudes appear well enough in the stage of associating. The obstacle in this stage is lack of groups' timing in finishing the tasks in the stage. Among the three attitudes which are demanded to appear in this stage, students' responsible attitude in finishing the tasks punctually is still low.

5. Stage of Communicating 
The last stage in chemical learning design containing verses of $\mathrm{Al}$ Qur'an is the stage of communicating. After passing sequence of the previous stages, in the end the students are demanded to share the discussion results of their groups with the discussion results of the other groups. It is done by doing visit work.

Visit work is an activity of communicating by bringing the groups' works to be presented in front of the other groups. The implementation of visit work is set in such a way that in one group, there are two people who have a task to visit other groups, bringing the works which have been compiled; those are, the answers of the worksheet questions which are written on sticky notes and are stuck on plano papers (intact sheet paper). Apart from two people who have a task to visit the other groups, there are some members of groups who have a task to comment on the results of the other groups' works that visit and present their works. In the stage of communicating, the attitudes which are shown are communicative, curious, cooperative and responsible attitudes. Generally the responsible attitude appears well when all the members of groups work in accordance with their roles, each of them is the person who does and accepts the visit works. The cooperative attitude can be said good, because between one group and the others have mutually listened and completed shortcomings in the task of visit works. The communicative attitude can be seen when the students who present their works explain the answers of groups' worksheets, while the curious attitude can be seen when the students comment and ask about their friends' group works.

The percentage average of the students' activities in each stage of electrochemistry learning containing verses of Al-Qur'an can be described in the chart as seen in Figure 2.

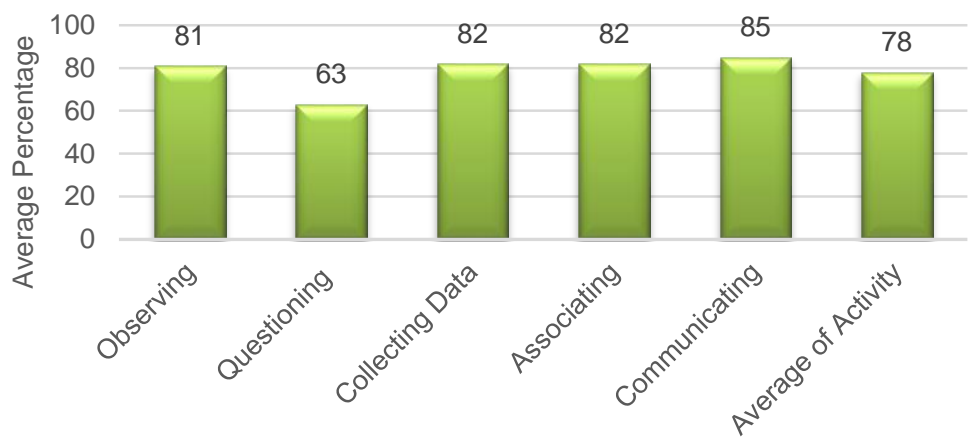

Figure 2. The average percentage of the students' activities in the stage of chemical learning design containing verses of Al-Qur'an 
The above chart shows that the stage of communicating gets the highest percentage. It reaches $85 \%$ with very good interpretation, while the stage of questioning gets the lowest percentage. It reaches $63 \%$ with good interpretation. Basically, the average of percentage value of the students' activities in the five stages of electro chemistry learning design containing verses of Al-Qur'an reaches $78 \%$ with good interpretation. The stage of communicating reaches the highest point. It occurs because the students are accustomed to presenting the discussion results or the others in accordance with the given tasks. Being different from the ability of questioning which tends to be still low, some students are still not yet courageous to express opinions because they are afraid of making mistakes, especially the students who do not prepare the material which will be learned, so that they are confused to submit questions. Such improvement of students' character is continually done to train and coordinate as well as motivate the students, so that they are capable and courageous to submit the quality questions. Being courageous to submit questions indicates the emergence of curious character.

\section{Analysis of Students' Character Builder in the Learning of Electro chemistry by Internalizing Verses of Al-Qur'an}

Students' attitudes which appear in the learning are measured by using two instruments, namely: observation sheet and questionnaire. The first instrument is attitude observation sheet. Students as many as 95 people are grouped into 20 groups. Students' attitudes in each group are observed by observer. The observer's task is to record students' attitudes which appear in the learning.

The used observation sheet consists of explanation of attitude aspects which reflects the curious, responsible, cooperative and communicative attitudes. Besides using the attitude observation sheet, students' attitudes are measured further by using self-assessment questionnaire. The questionnaire contains some opinion statements and some situation. After the statements are provided, columns must be filled with sequence from 'extremely agree' to 'extremely not agree'. Details in the questionnaire reflect the religious, curious, responsible, cooperative and communicative characters. Selfassessment questionnaire is filled by students after the learning.

Data analysis from observation results is done by seeking score average for each graded attitude aspect. The data are processed based on the learning group, then conclusion can be drawn from data tabulation on the whole. The first thing which is done is counting the answer frequency to each assessment scale. After gaining the right total, the total score is counted, is averaged and is divided by total respondent. The average from the generated final value is standard reference. If the final value for character is under the average value, 
then the emergence of the character is considered low. On the contrary, if the final value for character is above the average, then it can be concluded that the emergence of the character is high already.

The result of data tabulation for attitude observation can be seen from the average value of the students' characters presented in the Figure 3.

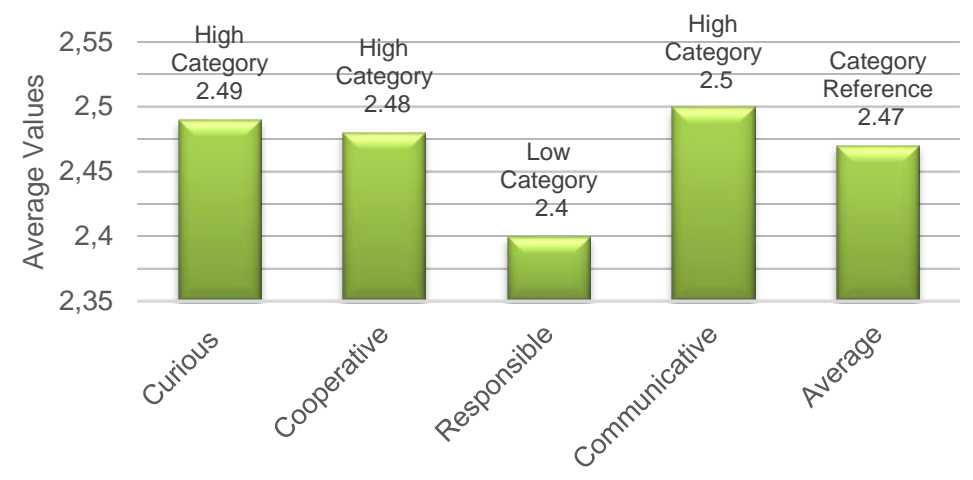

Figure 3. Character Builder Values from Observation Result.

Based on the chart above, students' most prominent character is communicative. Moreover, the curious and cooperative attitudes are also the characters which appear well from every student. One of the characters whose emergence is considered less is responsible character. This is also supported by questionnaire data which indicate that students' responsible attitude is not optimal yet.

Data analysis for self-assessment questionnaire is done like the steps in the analysis of attitude observation sheet. The difference is, the attitude observation sheet attaches value scale 3, 2 and 1 with each interpretation as good, enough and less, while the sequence which is in self-assessment questionnaire is extremely agree, agree, neutral, not agree, and extremely not agree. If a statement is positive, then the choice for 'extremely agree' is given score 5 and the choice for 'extremely not agree' is given score 1. On the contrary, if a statement is negative, then the choice for 'extremely agree' is given score 1, while the choice for 'extremely not agree' is given score 5 .

One of the characters which cannot be measured by observation is religious character. This character cannot be outlined as an indicator which can be observed by an observer. Therefore, the religious attitude is measured only with self-assessment questionnaire. Based on the research, the average value for students' religious attitude is the highest value and is above the whole average value. This indicates that the students have behaved religious. Figure 4 is the chart which describes the average value of the students' attitude based on the questionnaire. 


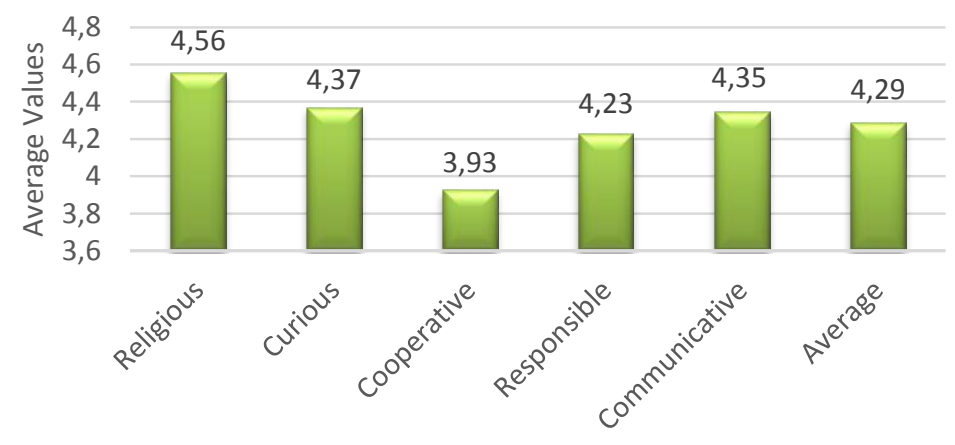

Figure 4. Characteristic Shaper Values from Questionnaire Result.

Based on self-assessment questionnaire, it is the cooperative character which is still low. However, based on the observation, cooperative character has appeared well, since the observer focused more on observing in group. While for the results of individual questionnaire, the students do selfassessment. The research makes information that the students still have not felt the existence of cooperation in the learning. It needs developing continually through lecture activities in order that the cooperative character becomes the internalized character in students. Responsible character from either the result of questionnaire or the result of observation still includes the low category or is under the average. The characteristic values including the responsible character can be internalized through the habits which are continually controlled. The positive habits both inside the class and outside the class accompanied by controlling will accelerate the internalization of character builder values such as religious, responsible, cooperative, communicative, and so forth. It is necessary to avoid the act of letting make mistakes without any sanctions or reprimands, since a doer tends to make the same mistakes again. In the end it will elicit the unexpected negative characters.

\section{CONCLUSION}

Based on the observation results during the process of the electro chemistry learning by internalizing verses of $\mathrm{Al}-\mathrm{Qur}$ 'an, the feasibility runs well which is indicated with the average of students' activities, and each learning stage reaches $78 \%$. The characters which are well identified through the observation when the learning takes place are religious, curious, cooperative and communicative by gaining the average value which is bigger than its limiter average. This points out that the four characters have appeared well when the learning takes place, while the responsible character has not 
appeared well. It means that the students need to do an increase in the next learning. The results of research show that the application of electrochemistry learning which is integrated with Al-Qur'an can internalize the values of students' character builder.

\section{BIBLIOGRAPHY}

Achmad, H. (2001). Elektrokimia dan Kinetika Kimia. Bandung: PT. Citra Aditya Bakti.

Andriansyah, M. (2015). Pesta Narkoba dan Seks saat Valentin 3 Muda-mudi diamankan. Merdekacom. http://www.merdeka. com/peristiwa/pestanarkoba-seks-saat-valentine-3-muda-mudi-diamankan.html. Tanggal 20 Maret 2015.

Chang, R. (2005). Kimia Dasar: Konsep-konsep Inti, Jilid 2 (Ed.Ketiga). Terjemahan oleh S. S. Achmadi. Jakarta: Erlangga.

Gunawan, H., (2012). Pendidikan Karakter Konsep dan Implementasi. Bandung: Alfabeta.

Hasanah, A. (2013). Pendidikan Karakter Berpersfektif Islam. Bandung: Insan Komunika.

Handayani. (2015). Rayakan Kelulusan, Beredar Undangan Pesta Bikini Siswi SMA. Solopos.com. http://www.solopos. com/2015/04/23/undangan-pesta-bikini-banjir-hujatan-pesta-bikinisiswi-sma-batal-597685, 30 April 2015.

Kemendikbud. (2013). Permendikbud No. 69 tentang Kurikulum SMA-MA. Jakarta: Kementerian Pendidikan dan Kebudayaan.

Kemendiknas. (2011). Panduan Pelaksanaan Pendidikan Karakter. Jakarta: Pusat Kurikulum dan Perbukuan.

Lutfiyah, H. (2014). Pengembangan Keterampilan Berpikir Kritis Mahasiswa melalui Praktikum Titrasi Reduksi Oksidasi Berbasis Diagram Alir pada Mata Kuliah Kimia Analaitik II. Skripsi. Bandung: UIN Sunan Gunung Djati. Tidak Diterbitkan.

Nugroho, A. (2008). Biologi, Sains, Lingkungan, dan Pembelajarannya Menuju Pembangunan Karakter. Makalah disajikan pada Seminar Nasional VIII Pendidikan Biologi, Surakarta.

Pemerintah Republik Indonesia. (2003). Undang-undang Republik Indonesia No. 17 Tahun 2007 tentang Rencana Pembangunan Jangka Panjang Nasional (RPJPN) Tabun 2005-2025. Jakarta. 